\title{
Overview of the pre-clinical and clinical studies about the use of CAR-T cell therapy of cancer combined with oncolytic viruses
}

\author{
Ali Zarezadeh Mehrabadi ${ }^{2}$, Fatemeh Roozbahani ${ }^{3}$, Reza Ranjbar ${ }^{4}$, Mahdieh Farzanehpour ${ }^{1}$, Alireza Shahriary ${ }^{5}$, \\ Ruhollah Dorostkar ${ }^{1}$ and Hadi Esmaeili Gouvarchin Ghaleh ${ }^{1 *}$ (D)
}

\begin{abstract}
Background: Cancer is one of the critical issues of the global health system with a high mortality rate even with the available therapies, so using novel therapeutic approaches to reduce the mortality rate and increase the quality of life is sensed more than ever.

Main body: CAR-T cell therapy and oncolytic viruses are innovative cancer therapeutic approaches with fewer complications than common treatments such as chemotherapy and radiotherapy and significantly improve the quality of life. Oncolytic viruses can selectively proliferate in the cancer cells and destroy them. The specificity of oncolytic viruses potentially maintains the normal cells and tissues intact. T-cells are genetically manipulated and armed against the specific antigens of the tumor cells in CAR-T cell therapy. Eventually, they are returned to the body and act against the tumor cells. Nowadays, virology and oncology researchers intend to improve the efficacy of immunotherapy by utilizing CAR-T cells in combination with oncolytic viruses.
\end{abstract}

Conclusion: Using CAR-T cells along with oncolytic viruses can enhance the efficacy of CAR-T cell therapy in destroying the solid tumors, increasing the permeability of the tumor cells for T-cells, reducing the disturbing effects of the immune system, and increasing the success chance in the treatment of this hazardous disease.

In recent years, significant progress has been achieved in using oncolytic viruses alone and in combination with other therapeutic approaches such as CAR-T cell therapy in pre-clinical and clinical investigations. This principle necessitates a deeper consideration of these treatment strategies. This review intends to curtly investigate each of these therapeutic methods, lonely and in combination form. We will also point to the pre-clinical and clinical studies about the use of CAR-T cell therapy combined with oncolytic viruses.

Keywords: Chimeric antigen receptor T cells (CART cells), Combined approaches, Oncolytic viruses, Cancers

\section{Background}

Cancer is a lethal disease discriminated by long-term inflammation [1]. Cancer impacted almost 19 million patients in 2020, and 10 million people died due to it. Thus, developing a stable infrastructure for preventing

\footnotetext{
${ }^{*}$ Correspondence: h.smaili69@yahoo.com

Applied Virology Research Center, Baqiyatallah University of Medical Sciences, Tehran, Iran

Full list of author information is available at the end of the article
}

and caring activities is indispensable for this world health issue [2].

Cancer treatment involves a wide range of modalities, including chemotherapy, radiotherapy, surgery, and medications such as monoclonal antibodies [3]. Additionally, physicians and researchers in this field are now looking for new approaches with higher efficacy, specificity, and fewer complications. Adoptive cell transfer (ACT) and oncolytic viruses are two novel therapeutic methods; original author(s) and the source, provide a link to the Creative Commons licence, and indicate if changes were made. The images or other third party material in this article are included in the article's Creative Commons licence, unless indicated otherwise in a credit line to the material. If material is not included in the article's Creative Commons licence and your intended use is not permitted by statutory regulation or exceeds the permitted use, you will need to obtain permission directly from the copyright holder. To view a copy of this licence, visit http://creativecommons.org/licenses/by/4.0/. The Creative Commons Public Domain Dedication waiver (http://creativeco mmons.org/publicdomain/zero/1.0/) applies to the data made available in this article, unless otherwise stated in a credit line to the data. 
several clinical trials are being conducted regarding these modalities.

Engineered T-cells expressing chimeric antigen receptors (CARs) specific to cancer cells have recently attracted much attention. CARs are recombinant receptors typically targeting surface molecules (here, cancer cell surface molecules) [4]. Generally, CARs include three main components: an extracellular antigen recognition domain of the single-chain fragment variant $(\mathrm{scFv})$ region, a transmembrane domain, and an intra-

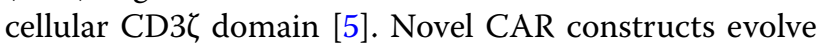
by adding co-stimulatory domains or targeting domains [6]. Autologous CAR-T cells can attack cancer cells and destroy them specifically.

CAR-T cell therapy is more effective in treating hematologic malignancies than solid tumors. For example, using CAR-T cells expressing anti-CD19 antigens (PAN B cell marker) has successfully treated acute lymphoblastic B-cell cancer of the children, non-Hodgkin lymphoma, and chronic lymphocytic leukemia [7].

The concept of immunotherapy in cancer has attracted the attention of physicians for centuries; thus, the relationship between microbial infection and mediated spontaneous tumor inhibition has been frequently assessed and discussed [8]. In the seventeenth to nineteenth centuries, different types of immunotherapy have been widely used. Two critical instances are using septic bandages for ulcerative tumor treatment and leaving surgical wounds open deliberately to accelerate wound healing [9]. According to the medical records of William Cole, the surgeon, he has treated cancer patients with bacterial lysates [10]. Oncolytic viruses selectively attack cancer cells, infect and lyse them, though they do not infect healthy cells. The oncolytic viruses are either wild viruses or laboratory-modified wild viruses. By using biotechnological approaches, a new era of viral-based therapies has started to cause fewer complications for the patients [11, 12]. In addition to oncolytic activity, OVs are very effective in stimulating inflammation and immune response against themselves and the tumor cells. However, the outcome of the immune response is associated with some complexities; the OV-mediated anti-tumor immunity is eventually effective $[10,13]$. Many OVs act like vaccines and lead to robust and specific TCD8 +-mediated antitumor reactions, which are frequently associated with the formation of significant memory cells $[14,15]$. Conclusively, OVs may turn into an effective therapeutic modality in treating various types of tumors soon. In cancer treatment, gene therapy is defined as using genetic molecules to manipulate target cells and tissues to treat cancer patients [16]. Two types of gene therapy modalities have been proven effective in recent years, including using CAR-T cells and oncolytic viruses for tumor treatment.
Oncolytic viruses are independently ineffective in the treatment of cancers, especially giant and metastatic tumors. Hence, oncolytic viruses can be used in combination with other treatments [17], including immune checkpoint blockers [18] and CAR-T cell therapy [19]. The combination of oncolytic viruses and CAR-T cells can be considered a new complementary strategy to overcome the limitations of using each of these therapies alone. This review aims to highlight the importance of CAR-T cells and oncolytic viruses as well as their use in monotherapy and combination therapy.

\section{Overview of oncolytic viruses}

Viruses are intracellular infectious particles that rely on the host cells for survival and proliferation; viral particles lead to pathogenesis and inflammation in the host cells [20]. Viruses are composed of three main parts: Genome is the innermost part of the viral particles (RNA or DNA) surrounded and protected by a protein coating called a capsid. The outermost part of the viral particles is the lipid coating or envelope, which facilitates viral binding to the host cells. Oncolytic viruses have no difference, though DNA oncolytic viruses are superior to other viruses due to their more giant genome, high stability of their polymerase enzyme, genome homogeneity, and high proliferative ability [21]. RNA viruses are suitable for tumors of the central nervous system due to their small size and ability to cross the blood-brain barrier [22].

Using viruses in cancer therapy dates back to the early nineteenth century as the reported treatment of patients with leukemia following viral infections. In the 1950s and 1960s, our viral knowledge expanded acknowledgments to the significant advancements of cell culture systems. Viral therapy attracted particular attention, and many viruses such as hepatitis, West Nile, and Epstein-Barr virus were frequently used in cancer treatment. These studies provided valuable information despite the variable and controversial results [23-25]. Some of these studies provided promising results. For example, in 1956, 30 female patients with advanced epidermoid cancer of the cervix were treated with adenovirus. In most patients, tumor region necrosis was observed, which was limited to the cancer tissue leading to no damage to the healthy tissue [26]. In the 1970s and 1980s, using viruses as a cancer therapeutic method was neglected; two decades later, this therapeutic method re-emerged under the title of "oncolytic viruses" [24].

In recent years, virotherapy for cancer has remarkably progressed. Moreover, these viruses may be used for cancer treatment due to their unique characteristics. Talimogenge lahreparepvec [T-vec] was the first oncolytic virus identified and registered for treating irrecoverable metastatic melanoma in the USA in 2015 [27, 28]. This virus 
infected and hit tumor cells, stimulated macrophages, and dendritic cells with pattern recognition receptors (PRP) through pathogen-associated molecular patterns [PAMP] released from killed tumor cells [20,29]. On the other hand, oncolytic viruses lead to DAMP production and activation of dendritic cells through tumor tissue destruction [30], and eventually, mature dendritic cells activate anti-tumor $\mathrm{T}$ cells by presenting tumor epitopes [31].

Some strategies such as using tumor-specific promotor and modification of viral protein may improve the oncolytic efficiency of the viruses, allowing the viral particles to merely infect tumor tissue without affecting healthy tissue [32]; moreover, antibodies, cytokines, and immune stimulants could be associated with the viral particles so that viral particles tolerate the tumor microenvironment and improve the efficacy [33].

Some oncolytic viruses, including parvoviruses, reoviruses, Newcastle disease virus, myxoma virus, Seneca Valley virus, and coxsackievirus, naturally have the ability of target cell recognition [34, 35]. These viruses proliferate after inserting the cells and releasing tumor-specific antigens, danger signals, interferon I production, and eventually tumor lysis and destruction [30]. They selectively enter their target cells (tumors) and do not infect healthy cells, though they induce immunity to other cells. On the other hand, some viruses, including adenovirus, herpes simplex virus, rubella virus, poliovirus, and vesicular stomatitis virus, do not inherit this feature and require genetic modification [34] (Table 1).

In 1999, immune response induction by oncolytic cells was recognized via oHSV for the first time. This virus acted as an "in situ cancer vaccine" and induced tumorspecific CTL and tumor cell death by the effector T cells against inoculated tumors [15].

Like gene therapy, desired genes for proper intracellular function may be added to oncolytic viruses to substitute viral genes [36]. One of the fantastic ways that can be used to kill tumors is to induce a "suicide gene" in tumor cells [37]. It is noteworthy that desired tumorassociated antigens may bond to the oncolytic viruses' surface through electrostatic bindings, even without gene therapy or genetic engineering [38].

\section{Overview of CAR-T and CAR-NK cell therapies}

In the last years, genetically modified immune cells, mainly T cells and natural killer (NK) cells that express chimeric antigen receptors (CARs), have had significant success in killing cancer cells [39]. CARs expressed on $\mathrm{T}$ or NK cells can enable them to detect a specific antigen expressed on tumor cells in the patient. CARs include three main components: an extracellular domain for tumor antigen recognition, a transmembrane domain, and one or more intracellular signaling domains leading to T-cell activation. The single-chain fragment variable ( $\mathrm{scFv}$ ) of a CAR, typically consists of variable heavy $(\mathrm{VH})$ and variable light (VL) chains of an antibody which are bonded by a linker peptide SCFV, binds to an intracellular signaling molecule composed of a $\mathrm{CD} 3 \zeta$ signaling domain or an intracellular signaling immunoreceptor tyrosinebased activation motif (ITAM). On the other hand, co-activator molecules such as CD28 and 4-1BB may be involved in the intracellular domain of the CAR. The main advantage of CAR-based methods for cancer immunotherapy is that SCFV shows a considerably higher affinity for antigen binding compared with TCR. Moreover, unlike TCR, SCFV acts in an MHCindependent manner [40, 41].

CAR T or NK cell therapy process comprises several steps that can take several weeks. First, T or NK cells are isolated from the patient's or donor's blood through leukapheresis, and thereupon genetically modified ex vivo, using viral or non-viral transfection methods. The CAR-modified immune cells are then grown and multiplied in the laboratory until sufficient cell numbers are produced. When the CAR T or NK cells are prepared, the patient receives a brief lymphodepleting chemotherapy course, followed by CAR T or NK cell infusion [42].

More than 450 clinical trials analyze CAR-T cells to treat cancer, especially hematological malignancies [42]. Among these clinical trials, CD19-directed CAR T cells have shown remarkable anti-cancer activity in patients with B-cell malignancies. In total, the CAR-T cells have demonstrated fabulous clinical responses in the treatment of mostly relapsed or refractory hematological malignancies that led to four FDA-approved CAR T cell therapy including Kymriah, Yescarta, Tecartus, and Breyanzi over the past 4 years [42-44]. Despite the significant success in the treatment of malignancies, CAR $\mathrm{T}$ cell therapy has shown several challenges. First, treatment with CAR $T$ cells can cause serious side effects, such as cytokine release syndrome (CRS) and immune effector cell-associated neurotoxicity syndrome (ICANS) [45]. Second, the autologous CAR T cell-manufacturing process can be long, costly, and laborious. Based on these limitations, other subsets of immune cells, such as natural killer (NK) cells, have received more attention in immunotherapy [46].

Up to now, 19 clinical trials involving CAR NK cells have been reported for the treatment of malignancies [42]. It seems that CAR NK cells can act as an alternative therapy option to CAR-T cells due to an intrinsic killing capacity of malignant cells and only a few adverse events related to insertional mutagenesis. CRS typically 
Table 1 A summary of the oncolytic viruses and their characteristics

\begin{tabular}{|c|c|c|c|c|c|c|}
\hline Features Viruses & $\begin{array}{l}\text { Engineered viruses } \\
\text { in studies }\end{array}$ & Particle size & $\begin{array}{l}\text { Cell entry } \\
\text { mechanism }\end{array}$ & Immunogenicity & Advantages & Disadvantages \\
\hline \multirow[t]{3}{*}{$\begin{array}{l}\text { Adenoviruses } \\
\text { (dsDNA) }\end{array}$} & $\begin{array}{l}\text { 1. ONYX-015 in head } \\
\text { and neck cancer }\end{array}$ & \multirow[t]{3}{*}{$32 \mathrm{~kb}$} & \multirow[t]{3}{*}{ Endocytosis } & \multirow[t]{3}{*}{ Low } & \multirow{3}{*}{$\begin{array}{l}\text { - Can be controlled } \\
\text { geneticall } \\
\text { - Clinical trial } \\
\text { encounter } \\
\text { - Great information of } \\
\text { viral protein work } \\
\text { - Low pathogenicity }\end{array}$} & \multirow[t]{3}{*}{$\begin{array}{l}\text { - Replication cannot be } \\
\text { easily shut-off }\end{array}$} \\
\hline & $\begin{array}{l}\text { 2.DNX-2401 } \\
\text { (delta-24-RGD) in } \\
\text { ovarian cancer }\end{array}$ & & & & & \\
\hline & $\begin{array}{l}\text { 3. CG0070 in } \\
\text { nonmuscle invasive } \\
\text { bladder cancer }\end{array}$ & & & & & \\
\hline \multirow[t]{2}{*}{$\begin{array}{l}\text { Herpes simplex } \\
\text { virus (dsDNA) }\end{array}$} & $\begin{array}{l}\text { 1. T-VEC (talimogene } \\
\text { laherparepvec) in } \\
\text { melanoma }\end{array}$ & \multirow[t]{2}{*}{$152 \mathrm{~kb}$} & \multirow[t]{2}{*}{$\begin{array}{l}\text { Endocytosis; pen- } \\
\text { etration }\end{array}$} & \multirow[t]{2}{*}{ Low } & \multirow{2}{*}{$\begin{array}{l}\text { - Can be easily } \\
\text { manipulated geneti- } \\
\text { cally } \\
\text { - Clinical trial experi- } \\
\text { ence; drugs exist to } \\
\text { shut-off unwanted } \\
\text { viral replication }\end{array}$} & \multirow{2}{*}{$\begin{array}{l}\text { - Side impacts incorpo- } \\
\text { rate genuine or pos- } \\
\text { sibly lethal disease } \\
\text { - Unknown activity } \\
\text { of numerous HSV1 } \\
\text { qualities }\end{array}$} \\
\hline & $\begin{array}{l}\text { 2. HF10 in pancreatic } \\
\text { cancer }\end{array}$ & & & & & \\
\hline \multirow[t]{2}{*}{$\begin{array}{l}\text { Pox virus (vaccinia } \\
\text { virus) (dsDNA) }\end{array}$} & \multirow[t]{2}{*}{$\begin{array}{l}\text { Pexa-Vec(JX-594) in } \\
\text { primary hepatocel- } \\
\text { lular carcinoma }\end{array}$} & \multirow[t]{2}{*}{$130-375 \mathrm{~kb}$} & \multirow[t]{2}{*}{$\begin{array}{l}\text { Membranepenetra- } \\
\text { tion and fusion }\end{array}$} & \multirow[t]{2}{*}{ High } & \multirow{2}{*}{$\begin{array}{l}\text { - Can be easily } \\
\text { manipulated geneti- } \\
\text { cally } \\
\text { - Clinical trial experi- } \\
\text { ence } \\
\text { - Stable in human } \\
\text { serum } \\
\text { - Excellent human } \\
\text { safety } \\
\text { - Large capacity for } \\
\text { encoding transgenes } \\
(50 \text { kb) } \\
\text { - Anti-tumor vascular } \\
\text { activity }\end{array}$} & $\begin{array}{l}\text { - Undesired viral repli- } \\
\text { cation cannot be easily } \\
\text { shut-off }\end{array}$ \\
\hline & & & & & & $\begin{array}{l}\text { - Unknown action of } \\
\text { many genes } \\
\text { - Side effects might } \\
\text { include potentially } \\
\text { fatal or seriously mor- } \\
\text { bid disease }\end{array}$ \\
\hline $\begin{array}{l}\text { Poliovirusss (+) } \\
\text { RNA }\end{array}$ & $\begin{array}{l}\text { PVS-RIPO in recurrent } \\
\text { glioblastoma }\end{array}$ & $7.5 \mathrm{~kb}$ & $\begin{array}{l}\text { Receptor-mediated } \\
\text { endocytosis }\end{array}$ & Moderate & $\begin{array}{l}\text { - Good knowledge of } \\
\text { viral gene functions }\end{array}$ & $\begin{array}{l}\text { - Cannot be easily } \\
\text { manipulated geneti- } \\
\text { cally } \\
\text { - No clinical trial experi- } \\
\text { ence } \\
\text { - Viral replication can- } \\
\text { not be easily shut-off } \\
\text { - Associated with fatal- } \\
\text { ity or serious disease }\end{array}$ \\
\hline $\begin{array}{l}\text { Measles virusss (-) } \\
\text { RNA }\end{array}$ & $\begin{array}{l}\text { MV-NIS in ovarian } \\
\text { cancer }\end{array}$ & $16 \mathrm{~kb} \sim$ & Membrane fusion & Low & $\begin{array}{l}\text { - Extensively studied } \\
\text { - Easily manipulated } \\
\text { - Genomic stability } \\
\text { - No integration into } \\
\text { host genome } \\
\text { - Adjustable gene } \\
\text { - Crossing of physi- } \\
\text { ological membranes }\end{array}$ & $\begin{array}{l}\text { Preexisting immune } \\
\text { response due to vac- } \\
\text { cination }\end{array}$ \\
\hline ReovirusesdsRNA & $\begin{array}{l}\text { RT3D }\left(\text { Reolysin }{ }^{\circledR}\right) \\
\text { in head and neck } \\
\text { cancer }\end{array}$ & $22-27 \mathrm{~kb}$ & Endocytosis & Low & $\begin{array}{l}\text { - Associated with } \\
\text { relatively mild } \\
\text { diseases } \\
\text { - Good knowledge of } \\
\text { viral gene function } \\
\text { - Growth advantage } \\
\text { in human cells }\end{array}$ & $\begin{array}{l}\text { - Cannot be easily } \\
\text { manipulated geneti- } \\
\text { cally } \\
\text { - No clinical trial experi- } \\
\text { ence } \\
\text { - Viral replication can- } \\
\text { not be easily shut-off }\end{array}$ \\
\hline
\end{tabular}

develops after CAR T cell administration due to elevated proinflammatory cytokines, such as IL-1, IL-6, and TNF $\alpha$ [47].

Notably, CAR NK cells are considered safe because they mainly secrete IFN- $\gamma$ and GMCSF. In addition, the approved CAR $\mathrm{T}$ cell products have been autologous through the risk of graft-versus-host disease (GVHD) with the use of allogeneic T cells. Several clinical studies have shown that, unlike allogeneic $\mathrm{T}$ cells, allogeneic NK cells do not cause GVHD [48]. 
According to pre-clinical and clinical studies, CAR NK cell therapy is a considerable anti-cancer agent and is safer than CAR-T cell therapy [46]. Nonetheless, CARNK cell therapy encounters some limitations, such as the expansion and activation of primary NK cells in vitro, the hardness of storing and shipping NK cell products (due to the sensitivity of NK cells to cryopreservation), and the low transduction efficiency. Therefore, further research is still required to optimize CAR NK cell therapy [39, 42].

\section{Combining oncolytic viruses with CAR T cell therapy}

Chimeric antigen receptor (CAR) T cell therapy has generated significant excitement in managing hematological malignancies, but solid tumors pose various challenges. It seems that combinations of different targeted therapies may be required to attain efficient and complete responses in solid tumors [49]. Oncolytic viruses as potential anti-tumor agents can help CAR T cells simultaneously overcome some of the limitations found in solid tumors [21].

Generally, the anti-tumor function of tumor-targeting CD8 + T-cells depends on three signals, including TCR engagement, co-stimulation, and an inflammatory stimulus. The second-and third-generation CARs provide engineered T-cells with TCR engagement and co-stimulation signaling [50]. The inflammatory stimulation of CAR T cells is typically driven by cytokines like IL-12 or type I IFNs. Type I IFNs are essential natural mediators of antiviral and anti-tumor activity by stimulating host adaptive immunity. It is identified that OVs can induce an elevated type I IFN signature in the tumor microenvironment [51].

In addition, many solid tumors intervene with tumorinfiltrating immune cells by diminishing adhesion molecule expression on endothelium, decreasing chemokine production, and secreting extracellular matrix components to prevent $\mathrm{T}$ cells from reaching the tumor microenvironment [52]. As mentioned, impaired CAR T-cell trafficking into solid tumors is one of the main challenges faced in applying CAR T cell therapy. Previous studies has shown that an inflammatory tumor microenvironment with active dendritic cells promotes type I IFNs and IFN- $\gamma$ secretion, and moreover co-stimulatory signals are essential for CAR $\mathrm{T}$ cell infiltration. Therefore, CAR T-cells are likely to benefit from the synergistic combination with OVs that enhanced CAR T cell migration into the tumor and persistence within the tumor microenvironment $[51,53]$.

The upregulation of programmed death ligand-1 (PDL1) on cancer cells negatively regulates $T$ cell function and contributes to cancer immune escape [54]. On the other hand, cancer cells also induce immunosuppressive signaling mediated by a variety of immune cells like
Tregs, tumor-associated macrophages (TAMs), myeloid-derived suppressor cells (MDSCs), fibroblasts, and endothelial cells within the tumor microenvironment. These immunosuppressive phenotypes impede effector T-cell exclusion and function within the tumor microenvironment. Overcoming these mechanisms of immunosuppression can improve the efficacy of immunotherapy, especially CAR $\mathrm{T}$ cell therapy in solid tumors. It seems that the combination of OVs and CAR-T cells can negate the multiple immunosuppressive mechanisms and enhance the effector functions of $\mathrm{T}$ cells $[52,55]$.

OVs have recently been generated by genetic modification to have co-stimulatory molecules including OX40L, 4-1BBL, and GITRL to boost the local activation and expansion of effector $\mathrm{T}$ cells within the tumor microenvironment [51]. Moreover, OVs have been designed with additional transgenes encoding CD40 ligand (CD40L), increasing local CD40 activation within the tumor microenvironment. Owing to the expression of CD40 on a wide range of immune cells, including $\mathrm{CD}_{4}^{+} \mathrm{T}$-cells, macrophages, and B-cells, activation of this pathway mediates anti-tumor immune responses [56].

Various pre-clinical research has evaluated different transgene-armed OV in combination with CAR-T cells [51]. The finding of these researches gave main insights into the anti-tumor impacts of CAR-T cells in combination with engineered-OVs (Fig. 1). Furthermore, the flexibility of the engineering process of OVs and CAR T cells can help researchers design the most appropriate combinations of recombinant OV and CAR T cell co-stimulation to the specific characteristics of the targeted tumor [57].

In fact, the immune-stimulatory properties of OVs and the potential to arm OVs with therapeutic transgenes make them excellent partners to boost CAR $T$ cells in vivo (Fig. 2). Nonetheless, the potential for combining OVs, CAR T-cell therapy, and an additional immunotherapeutic strategy are practically limitless [58]. Naturally, translation of pre-clinical experimental results to clinical trials cannot often be logical and acceptable because of using an immunodeficient mouse model (NOD SCID gamma mice), so this experimental system cannot model the interactions between $\mathrm{OV}$ and CAR $\mathrm{T}$ cells in the human immune system [59]. In addition, the double combination enhances concern about the safety of combining two potent proinflammatory immunotherapies. Finally, given that combining these two therapies is a new approach, many studies are needed to improve it.

\section{Use of oncolytic viruses in combination with CAR-T cell therapy in pre-clinical and clinical studies}

Scientist's achievements in recombinant genetic engineering sciences have led to significant progress in 

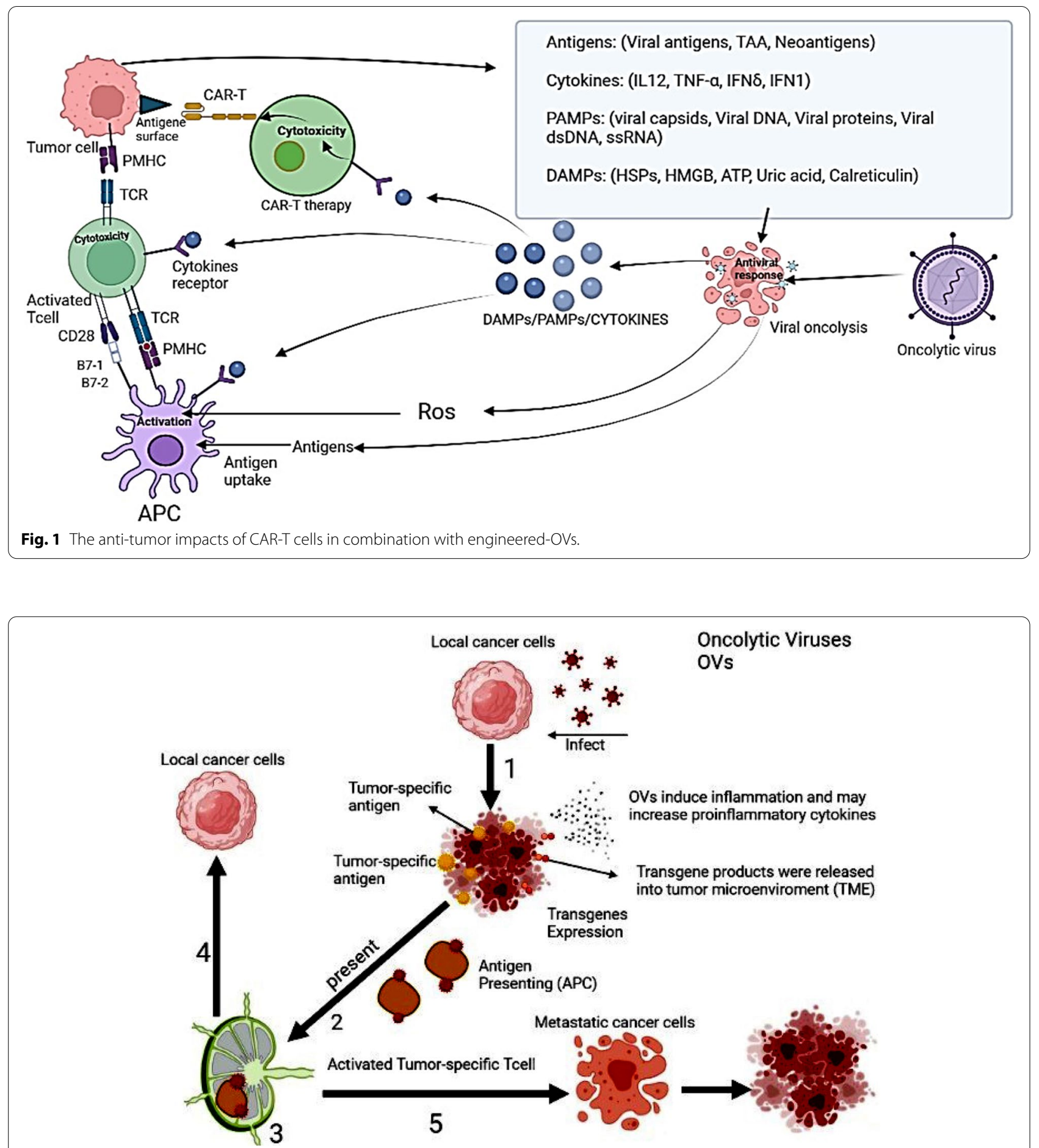

Fig. 2 Different levels of combined therapy of OVs with CAR-T cells. Oncolytic viruses exert their effects on cancer cells in a variety of ways. These viruses can lysis cancer cells to better activate APC cells, cause inflammation, and release inflammatory cytokines

oncolytic viruses' usage. By oncolytic viruses' genome editing, the ability of these viruses to destroy the tumor cells can be altered, and their oncotropic nature can be improved. Inserting the oncolytic viruses into the target cells could turn the cancer cells into cytokine and chemokine factories, thus modifying TME (tumor microenvironment) from an immunosuppressive environment to an immunostimulatory one to facilitate the 
summoning and induction of the immune cells (such as CAR-T cells) and factors [51]. Tumor cells will try to suppress the immune system, but after contaminating with oncolytic viruses, danger signals are sent, and therefore immune cells such as CD8 $+\mathrm{T}$ cells will arrive at the scene and destroy the tumor cells [60]. Until now, many manipulated oncolytic viruses have been used in pre-clinical and clinical steps of researches. The results of using oncolytic viruses and CAR-T cell therapy spontaneously in animal studies have been promising. In the following, we discuss the results of the clinical and preclinical studies about CAR-T cell therapy combined with oncolytic viruses.

In a study conducted by Anna Wing et al. on pancreatic ductal carcinoma/colorectal carcinoma, Onc. Ad-EGFR BITE adenovirus, which is armed by EGFR-targeting, a bispecific T-cell engager was used. Concomitant use of this engineered virus and the CAR-T cells containing 4-1BB endodomain and targeting folate receptor alpha (FR- $\alpha$ ) antigen will improve the function of the CAR-T cells. This happens because of the BITE secretion of the contaminated cancer cells. Although tumor cells are free of CAR-specific antigens (FR- $\alpha$ in here) but can be targeted and destroyed by the CAR-T cells thanks to BITE secretion, and this is where BITE importance is two folded [19]. Pancreatic ductal carcinoma has a highly immunosuppressive TME and increased Treg cells. So pancreatic tumors TME can disturb T-cell function [61, 62]. In a study relevant to this malignancy, they utilized the TNF- $\alpha$ and IL-2 expressing Onc.Ad-TNF- $\alpha / \mathrm{IL}-2$ oncolytic virus combining with Mesotheline (meso)-specific CAR-T cells containing 4-1 BB endodomain improved the efficiency of the anti-tumor activity of the CAR-T cells (in comparison with using it alone) in mouse models. This improvement in the efficiency of the CAR-T cells could be related to the local expression of the TNF- $\alpha$ and IL-2 in addition to the oncolysis characteristics of these viruses [63]. These cytokines could expand the number of tumor-infiltrating cells in the tumor microenvironment $[63,64]$.

Efficient animal studies have been performed in the combined oncolytic viruses and CAR-T cell therapy to treat other carcinomas such as head and neck carcinoma and neuroblastoma. Using of the Onc. Ad5 $\Delta 24$ virus (armed with RANTES chemokine and IL-15 cytokine) along with Ganglioside GD2-specific CAR-T cells to treat the tumors leads to an increase in the attraction and survival of the CAR-T cells in neuroblastoma tumor environment [65]. In research performed by Amanda Rosewell Shaw et al. on head and neck cancer metastasis, a type of binary oncolytic adenovirus named CAdVECIL12p70/ $\alpha$ PDL1 was employed in combination with human epidermal growth factor 2 (HER2)-specific CAR-T cells. The construct used in this study encoded the PD-L1 blocking antibody concomitantly with IL-12P70. Local production of the anti-PD-L1 in the tumor site is the advantage of this oncolytic virus [66]. Systemic applying the antibodies against the immune checkpoint blockers like PD-L1 and CTLA-4 can lead to unwanted manifestations such as autoimmunity and even tumor growth. Therefore, it appears that manipulated oncolytic viruses could reduce the inappropriate systemic effects of these treatments by local production of these antibodies $[67,68]$.

Oncolytic viruses can cooperate with lymphocytes against malignancies, but because there is an immune response against these viruses, therapeutic doses of them to dominate the immune responses, including antibodies, are very high $[69,70]$. To overcome this issue, Heather VanSeggelen et al. investigated using CAR-T cells loaded with low-dose oncolytic viruses. The results of this study disclosed that there is no difference in the CAR expression inside virus-loaded CAR-T cells with intact CAR-T cells, and there was no disturbance in the function of manipulated CAR-T cells. It can be said that CAR-T cells successfully transferred the virus to tumor cells [71]. Although this was an in vitro study, the results are auspicious since combining two treatment strategies comes to meaning only when there is no interference between the treatments. According to the results of this study, utilizing the "variable oncolytic virus-loaded CAR-T cells" can be suggested to future pre-clinical researches and survey the results of this novel method in animal models of cancer.

Many clinical trials about the use of oncolytic viruses in tumor treatment are on the line. In 2015, the FDA approved the talimogene laherparepvec (T-VEC) license for melanoma. T-VEC is an engineered HSV-1, which expresses human granulocyte-macrophage colonystimulating factor (GM-CSF). GM-CSF increases the summoning of the antigen-presenting cells to the tumor environment. T-VEC provokes tumor death with specific proliferation in the tumor cell and stimulates the specific immune system response against the tumor as a secondary function [72]. Applying T-VEC as a combination with chemotherapy [73], radiotherapy [74], and drugs like ipilimumab (anti-cytotoxic $\mathrm{T}$ lymphocyte antigen 4 antibody) [75] are available approaches to increase the efficiency of this therapeutic method. Therefore, considering these cases, the T-VEC and CAR T-cell combination can be investigated in the future. However, only one approved clinical trial investigated CAR $\mathrm{T}$ and $\mathrm{OV}$ combination therapy for HER2-positive tumors (NCT03740256) [76]. Selecting a particular combination of the oncolytic virus and a CAR vector relates to various items, such as the virus's ability to contaminate cells that are expressing CAR antigen. 


\section{Conclusion}

Tumor and their treatment have been one of the challenges in medical science until now. The FDA approval of two CAR-T cells against hematologic malignancies, tisagenlecleucel-T (Kymriah, Novartis) and axicabtagene ciloleucel (YesCAR Ta, Kite Phama), as well as the first OV (talimogene laherparepvec) for the treatment of melanoma, all are inspiring and significant advances in the field of cancer immunotherapy for the control and cure of an incurable disease. However, issues like possible pathogenicity of viable biologic agents, virus elimination by the immune system, not so high efficacy of CAR-T cell therapy in treating solid tumors, CAR-T cell-induced cytokine storms, and the same obstacles are very complex challenges in the road of clinical development. This review will discuss two cancer treatment approaches: CAR-T cell therapy and using the oncolytic viruses and combination use of them. It is demonstrated in preclinical studies and various animal models of cancer that using these treatments concomitantly is more efficient than using them alone. However, further investigations in this field to determine the appropriate virus, proper administration method, and finding possible complications are highly suggested. The combined use of CAR-T cell therapy and the oncolytic viruses can reduce the evading of the virus from immunotherapy. These discoveries enclose that this combined method can cause remarkable evolution in cancer treatment, especially solid tumors.

\section{Abbreviations \\ PMHC: Peptide-major histocompatibility complex; TAA: Tumor-associated antigen; PAMP: Pathogen-associated molecular pattern; DAMP: Damage- associated molecular pattern'; HSPs: Heat shock proteins.}

\section{Acknowledgements}

The authors wish to thank all staff of Applied Virology Research Center, Baqiyatallah University of Medical Science, Tehran, Iran, for their cooperation in implementing experimental procedures and analysis of data.

\section{Authors' contributions \\ $H E, R D$, and $A S$ conceived and designed the study. AZ, FR, RR, and MF wrote the manuscript and arranged the figures and table. HE and RD contributed to reviewing and editing the paper. All authors read and approved the final manuscript.}

\section{Funding}

There was no funding source for this study.

\section{Availability of data and materials}

The data achieved and analyzed during this study are available from the corresponding author on reasonable request.

\section{Declarations}

Ethics approval and consent to participate Not applicable
Consent for publication

Not applicable

\section{Competing interests}

The authors declare that they have no competing interests.

\begin{abstract}
Author details
${ }^{1}$ Applied Virology Research Center, Baqiyatallah University of Medical Sciences, Tehran, Iran. ${ }^{2}$ Immunology Department, School of Medicine, Iran University of Medical Sciences, Tehran, Iran. ${ }^{3}$ Department of Microbiology and Virology, Faculty of Medicine, Mazandaran University of Medical Sciences, Sari, Iran. ${ }^{4}$ Molecular Biology Research Center, Systems Biology and Poisonings Institute, Baqiyatallah University of Medical Sciences, Tehran, Iran. ${ }^{5}$ Chemical Injuries Research Center, Systems Biology and Poisonings Institute, Baqiyatallah University of Medical Sciences, Tehran, Iran.
\end{abstract}

Received: 22 September 2021 Accepted: 24 December 2021

Published online: 13 January 2022

\section{References}

1. Coussens LM, Werb Z. Inflammation and cancer. Nature. 2002;420(6917):860-7. https://doi.org/10.1038/nature01322.

2. Bray F, Ferlay J, Soerjomataram I, Siegel RL, Torre LA, Jemal A. Global cancer statistics 2018: GLOBOCAN estimates of incidence and mortality worldwide for 36 cancers in 185 countries. CA Cancer J Clin. 2018;68(6):394-424. https://doi.org/10.3322/caac.21492.

3. Bidram E, Esmaeili Y, Ranji-Burachaloo H, Al-Zaubai N, Zarrabi A, Stewart A, et al. A concise review on cancer treatment methods and delivery systems. J Drug Deliv Sci Technol. 2019;54: 101350. https://doi.org/10. 1016/j.jddst.2019.101350.

4. Xu Q, Harto H, Berahovich R, Xu S, Zhou H, Golubovskaya V, et al. Generation of CAR-T cells for cancer immunotherapy. Cancer Immunosurveillance: Springer; 2019. p. 349-60.

5. Styczyński J. A brief history of CAR-T cells: from laboratory to the bedside. Acta Haematol Pol. 2020;51(1):2-5. https://doi.org/10.2478/ ahp-2020-0002.

6. Brocker T. Chimeric Fv-zeta or Fv-epsilon receptors are not sufficient to induce activation or cytokine production in peripheral T cells. Blood. 2000;96(5):1999-2001. https://doi.org/10.1182/blood.V96.5.1999 Epub 2000/08/29. PubMed PMID: 10961908.

7. June $\mathrm{CH}$, Sadelain M. Chimeric antigen receptor therapy. N Engl J Med. 2018;379(1):64-73. https://doi.org/10.1056/NEJMra1706169.

8. Lizée G, Overwijk WW, Radvanyi L, Gao J, Sharma P, Hwu P. Harnessing the power of the immune system to target cancer. Annu Rev Med. 2013;64:71-90. https://doi.org/10.1146/annurev-med-112311-083918.

9. Kucerova P, Cervinkova M. Spontaneous regression of tumour and the role of microbial infection-possibilities for cancer treatment. Anticancer Drugs. 2016;27(4):269. https://doi.org/10.1097/CAD.0000000000000337.

10. Hemminki O, Dos Santos JM, Hemminki A. Oncolytic viruses for cancer immunotherapy. J Hematol Oncol. 2020;13(1):1-15. https://doi.org/10. 1186/s13045-020-00922-1.

11. Chiocca EA, Smith ER. Oncolytic viruses as novel anticancer agents: turning one scourge against another. Expert Opin Investig Drugs. 2000;9(2):311-27. https://doi.org/10.1517/13543784.9.2.311.

12. Hemminki $O$, Hemminki A. A century of oncolysis evolves into oncolytic immunotherapy. Oncoimmunology. 2016;5(2): e1074377. https://doi.org/ 10.1080/2162402X.2015.1074377.

13. Melcher A, Parato K, Rooney CM, Bell JC. Thunder and lightning: immunotherapy and oncolytic viruses collide. Mol Ther. 2011;19(6):1008-16. https://doi.org/10.1038/mt.2011.65.

14. Bartlett DL, Liu Z, Sathaiah M, Ravindranathan R, Guo Z, He Y, et al. Oncolytic viruses as therapeutic cancer vaccines. Mol Cancer. 2013;12(1):1-16. https://doi.org/10.1186/1476-4598-12-103.

15. Toda M, Rabkin SD, Kojima H, Martuza RL. Herpes simplex virus as an in situ cancer vaccine for the induction of specific anti-tumor immunity. Hum Gene Ther. 1999;10(3):385-93. https://doi.org/10.1089/1043034995 0018832 
16. Cross D, Burmester JK. Gene therapy for cancer treatment: past, present and future. Clin Med Res. 2006;4(3):218-27. https://doi.org/10.3121/cmr.4. 3.218.

17. Andtbacka R, Kaufman HL, Collichio F, Amatruda T, Senzer N, Chesney J, et al. Talimogene laherparepvec improves durable response rate in patients with advanced melanoma. J Clin Oncol. 2015;33(25):2780-8. https://doi.org/10.1200/JCO.2014.58.3377.

18. Chesney J, Puzanov I, Collichio F, Singh P, Milhem MM, Glaspy J, et al. Randomized, open-label phase II study evaluating the efficacy and safety of talimogene laherparepvec in combination with ipilimumab versus ipilimumab alone in patients with advanced, unresectable melanoma. J Clin Oncol. 2018;36(17):1658. https://doi.org/10.1200/ JCO.2017.73.7379.

19. Wing A, Fajardo CA, Posey AD, Shaw C, Da T, Young RM, et al. Improving CART-cell therapy of solid tumors with oncolytic virus-driven production of a bispecific T-cell engager. Cancer Immunol Res. 2018;6(5):605-16. https://doi.org/10.1158/2326-6066.CIR-17-0314.

20. Mogensen TH. Pathogen recognition and inflammatory signaling in innate immune defenses. Clin Microbiol Rev. 2009;22(2):240-73. https:// doi.org/10.1128/CMR.00046-08.

21. Kaufman HL, Kohlhapp FJ, Zloza A. Oncolytic viruses: a new class of immunotherapy drugs. Nat Rev Drug Discov. 2015;14(9):642-62. https:// doi.org/10.1038/nrd4663.

22. Haseley A, Alvarez-Breckenridge C, Chaudhury AR, Kaur B. Advances in oncolytic virus therapy for glioma. Recent Pat CNS Drug Discov. 2009:4(1):1-13.

23. Gey G. Tissue culture studies of the proliferative capacity of cervical carcinoma and normal epithelium. Cancer Res. 1952;12:264-5.

24. Kelly E, Russell SJ. History of oncolytic viruses: genesis to genetic engineering. Mol Ther. 2007;15(4):651-9. https://doi.org/10.1038/sj.mt.63001 08.

25. Weller TH, Robbins FC, Enders JF. Cultivation of poliomyelitis virus in cultures of human foreskin and embryonic tissues. Proc Soc Exp Biol Med. 1949;72(1):153-5. https://doi.org/10.3181/00379727-72-17359.

26. Smith RR, Huebner RJ, Rowe WP, Schatten WE, Thomas LB. Studies on the use of viruses in the treatment of carcinoma of the cervix. Cancer. 1956;9(6):1211-8. https://doi.org/10.1002/1097-0142(195611/12)9:6\% 3c1211::aid-cncr2820090624\%3e3.0.co;2-7.

27. Steele L, Errington F, Prestwich R, llett E, Harrington $\mathrm{K}$, Pandha $\mathrm{H}$, et al. Pro-inflammatory cytokine/chemokine production by reovirus treated melanoma cells is PKR/NF-KB mediated and supports innate and adaptive anti-tumour immune priming. Mol Cancer. 2011;10(1):1-13. https:// doi.org/10.1186/1476-4598-10-20.

28. Zell JA, Cinar P, Mobasher M, Ziogas A, Meyskens FL Jr, Anton-Culver H. Survival for patients with invasive cutaneous melanoma among ethnic groups: the effects of socioeconomic status and treatment. J Clin Oncol. 2008;26(1):66-675. https://doi.org/10.1200/JCO.2007.12.3604

29. Stojdl DF, Lichty B, Knowles S, Marius R, Atkins H, Sonenberg N, et al. Exploiting tumor-specific defects in the interferon pathway with a previously unknown oncolytic virus. Nat Med. 2000;6(7):821-5. https://doi.org/ 10.1038/77558.

30. Guo ZS, Liu Z, Bartlett DL. Oncolytic immunotherapy: dying the right way is a key to eliciting potent antitumor immunity. Front Oncol. 2014:4:74. https://doi.org/10.3389/fonc.2014.00074.

31. Pol J, Kroemer G, Galluzzi L. First oncolytic virus approved for melanoma immunotherapy. Oncoimmunology. 2015;5(1):e1115641. https://doi.org/ 10.1080/2162402X.2015.1115641.

32. Van Erp EA, Kaliberova LN, Kaliberov SA, Curiel DT. Retargeted oncolytic adenovirus displaying a single variable domain of camelid heavy-chainonly antibody in a fiber protein. Mol Ther Oncol. 2015;2:15001. https:// doi.org/10.1038/mto.2015.1.

33. Goradel NH, Mohajel N, Malekshahi ZV, Jahangiri S, Najafi M, Farhood $B$, et al. Oncolytic adenovirus: a tool for cancer therapy in combination with other therapeutic approaches. J Cell Physiol. 2019;234(6):8636-46. https://doi.org/10.1002/jcp.27850.

34. Chiocca EA, Rabkin SD. Oncolytic viruses and their application to cancer immunotherapy. Cancer Immunol Res. 2014;2(4):295-300. https://doi. org/10.1158/2326-6066.CIR-14-0015.

35. Dharmadhikari N, Mehnert JM, Kaufman HL. Oncolytic virus immunotherapy for melanoma. Curr Treat Options Oncol. 2015;16(3):10. https:// doi.org/10.1007/s11864-014-0326-0.
36. Zhang Y-F, Zhang B-C, Zhang A-R, Wu T-T, Liu J, Yu L-F, et al. Co-transduction of ribosomal protein $L 23$ enhances the therapeutic efficacy of adenoviral-mediated p53 gene transfer in human gastric cancer. Oncol Rep. 2013;30(4):1989-95. https://doi.org/10.3892/or.2013.2663.

37. Hall S, Canfield S, Yan Y, Hassen W, Selleck W, Chen S-H. A novel bystander effect involving tumor cell-derived Fas and FasL interactions following Ad. HSV-tk and Ad. mlL-12 gene therapies in experimental prostate cancer. Gene Ther. 2002;9(8):511-7. https://doi.org/10.1038/sj.gt.3301669.

38. Capasso C, Hirvinen M, Garofalo M, Romaniuk D, Kuryk L, Sarvela T, et al. Oncolytic adenoviruses coated with MHC-I tumor epitopes increase the antitumor immunity and efficacy against melanoma. Oncoimmunology. 2016;5(4): e1105429. https://doi.org/10.1080/2162402X.2015.1105429.

39. Wang L, Dou M, Ma Q, Yao R, Liu J. Chimeric antigen receptor (CAR)-modified NK cells against cancer: opportunities and challenges. Int Immunopharmacol. 2019;74:105695. https://doi.org/10.1016/j.intimp.2019.105695 Epub 2019/06/30. PubMed PMID: 31254958.

40. Feins S, Kong W, Williams EF, Milone MC, Fraietta JA. An introduction to chimeric antigen receptor (CAR) T-cell immunotherapy for human cancer. Am J Hematol. 2019;94(S1):S3-9. https://doi.org/10.1002/ajh.25418.

41. Lindner S, Johnson S, Brown C, Wang L. Chimeric antigen receptor signaling: functional consequences and design implications. Sci Adv. 2020;6(21):eaaz3223. https://doi.org/10.1126/sciadv.aaz3223.

42. Albinger N, Hartmann J, Ullrich E. Current status and perspective of CAR-T and CAR-NK cell therapy trials in Germany. Gene Ther. 2021. https://doi. org/10.1038/s41434-021-00246-w Epub 2021/03/24. PubMed PMID: 33753909 .

43. Yip A, Webster RM. The market for chimeric antigen receptor $T$ cell therapies. Nat Rev Drug Discov. 2018;17(3):161-2. https://doi.org/10.1038/nrd. 2017.266 Epub 2018/01/30. PubMed PMID: 29375140.

44. Ruella M, Kenderian SS. Next-generation chimeric antigen receptor T-cell therapy: going off the shelf. BioDrugs. 2017;31(6):473-81. https://doi.org/ 10.1007/s40259-017-0247-0 Epub 2017/11/17. PubMed PMID: 29143249; PubMed Central PMCID: PMCPMC5699508.

45. Levin A, Shah NN. Chimeric antigen receptor modified T cell therapy in B cell non-Hodgkin lymphomas. Am J Hematol. 2019;94(S1):S18-23. https://doi.org/10.1002/ajh.25403.

46. Daher M, Melo Garcia L, Li Y, Rezvani K. CAR-NK cells: the next wave of cellular therapy for cancer. Clin Transl Immunology. 2021;10(4):e1274. https://doi.org/10.1002/cti2.1274 Epub 2021/05/08. PubMed PMID: 33959279; PubMed Central PMCID: PMCPMC8080297.

47. Neelapu SS, Tummala S, Kebriaei P, Wierda W, Gutierrez C, Locke FL, et al. Chimeric antigen receptor T-cell therapy-assessment and management of toxicities. Nat Rev Clin Oncol. 2018;15(1):47-62. https://doi.org/10. 1038/nrclinonc.2017.148.

48. Passweg JR, Tichelli A, Meyer-Monard S, Heim D, Stern M, Kühne T, et al. Purified donor NK-lymphocyte infusion to consolidate engraftment after haploidentical stem cell transplantation. Leukemia. 2004;18(11):1835-8. https://doi.org/10.1038/sj.leu.2403524 Epub 2004/10/01. PubMed PMID: 15457184.

49. Rosewell Shaw A, Suzuki M. Oncolytic viruses partner with T-cell therapy for solid tumor treatment. Front Immunol. 2018;9:2103. https://doi.org/ 10.3389/fimmu.2018.02103.

50. Keppler SJ, Rosenits K, Koegl T, Vucikuja S, Aichele P. Signal 3 cytokines as modulators of primary immune responses during infections: the interplay of type I IFN and IL-12 in CD8T cell responses. PLoS ONE. 2012;7(7):e40865. https://doi.org/10.1371/journal.pone.0040865 Epub 2012/07/21. PubMed PMID: 22815848; PubMed Central PMCID: PMCPMC3398954.

51. Ajina A, Maher J. Prospects for combined use of oncolytic viruses and CAR T-cells. J Immunother Cancer. 2017;5(1):1-27. https://doi.org/10. 1186/s40425-017-0294-6.

52. McGrath K, Dotti G. Combining oncolytic viruses with chimeric antigen receptor T cell therapy. Hum Gene Ther. 2021;32(3 4):150-7. https://doi. org/10.1089/hum.2020.278 Epub 2020/12/23. PubMed PMID: 33349123; PubMed Central PMCID: PMCPMC8336251.

53. Curtsinger JM, Valenzuela JO, Agarwal P, Lins D, Mescher MF. Type I IFNs provide a third signal to CD8 T cells to stimulate clonal expansion and differentiation. J Immunol. 2005;174(8):4465-9. https://doi.org/10.4049/ jimmunol.174.8.4465 Epub 2005/04/09. PubMed PMID: 15814665.

54. Suarez ER, de Chang K, Sun J, Sui J, Freeman GJ, Signoretti S, et al. Chimeric antigen receptor $T$ cells secreting anti-PD-L1 antibodies more 
effectively regress renal cell carcinoma in a humanized mouse model. Oncotarget. 2016;7(23):34341-55. https://doi.org/10.18632/oncotarget. 9114 Epub 2016/05/05. PubMed PMID: 27145284; PubMed Central PMCID: PMCPMC5085160.

55. Munn DH, Bronte V. Immune suppressive mechanisms in the tumor microenvironment. Curr Opin Immunol. 2016;39:1-6. https://doi.org/ 10.1016/j.coi.2015.10.009 Epub 2015/11/27. PubMed PMID: 26609943; PubMed Central PMCID: PMCPMC5627973.

56. Liu GY, Li ZJ, Li QL, Jin Y, Zhu YH, Wang YH, et al. Enhanced growth suppression of TERT-positive tumor cells by oncolytic adenovirus armed with CCL20 and CD40L. Int Immunopharmacol. 2015;28(1):487-93. https:// doi.org/10.1016/j.intimp.2015.07.005 Epub 2015/07/25. PubMed PMID: 26208317.

57. Guedan S, Alemany R. CAR-T cells and oncolytic viruses: joining forces to overcome the solid tumor challenge. Front Immunol. 2018;9:2460. https://doi.org/10.3389/fimmu.2018.02460.

58. Guedan S, Alemany R. CAR-T cells and oncolytic viruses: joining forces to overcome the solid tumor challenge. Front Immunol. 2018;9:2460. https://doi.org/10.3389/fimmu.2018.02460 Epub 2018/11/09. PubMed PMID: 30405639; PubMed Central PMCID: PMCPMC6207052.

59. Morgan RA. Human tumor xenografts: the good, the bad, and the ugly. Mol Ther. 2012;20(5):882-4. https://doi.org/10.1038/mt.2012.73.

60. Endo Y, Sakai R, Ouchi M, Onimatsu H, Hioki M, Kagawa S, et al. Virusmediated oncolysis induces danger signal and stimulates cytotoxic T-lymphocyte activity via proteasome activator upregulation. Oncogene. 2008;27(17):2375-81. https://doi.org/10.1038/sj.onc.1210884.

61. John LB, Devaud C, Duong CP, Yong CS, Beavis PA, Haynes NM, et al. AntiPD-1 antibody therapy potently enhances the eradication of established tumors by gene-modified T cells. Clin Cancer Res. 2013;19(20):5636-46. https://doi.org/10.1158/1078-0432.CCR-13-0458.

62. Liyanage UK, Moore TT, Joo H-G, Tanaka Y, Herrmann V, Doherty G, et al. Prevalence of regulatory $T$ cells is increased in peripheral blood and tumor microenvironment of patients with pancreas or breast adenocarcinoma. J Immunol. 2002;169(5):2756-61. https://doi.org/10.4049/jimmu nol.169.5.2756.

63. Watanabe K, Luo Y, Da T, Guedan S, Ruella M, Scholler J, et al. Pancreatic cancer therapy with combined mesothelin-redirected chimeric antigen receptor T cells and cytokine-armed oncolytic adenoviruses. JCI Insight. 2018;3(7):e99573. https://doi.org/10.1172/jci.insight.99573.

64. Marshall D, Pedley R, Melton R, Boden J, Boden R, Begent R. Galactosylated streptavidin for improved clearance of biotinylated intact and $F$ (ab') 2 fragments of an anti-tumour antibody. Br J Cancer. 1995;71 (1):1824. https://doi.org/10.1038/bjc.1995.5.

65. Nishio N, Diaconu I, Liu H, Cerullo V, Caruana I, Hoyos V, et al. Armed oncolytic virus enhances immune functions of chimeric antigen receptor-modified T cells in solid tumors. Can Res. 2014;74(18):5195-205. https://doi.org/10.1158/0008-5472.CAN-14-0697.

66. Shaw AR, Porter CE, Watanabe N, Tanoue K, Sikora A, Gottschalk S, et al. Adenovirotherapy delivering cytokine and checkpoint inhibitor augments CART cells against metastatic head and neck cancer. Mol Ther. 2017;25(11):2440-51. https://doi.org/10.1016/j.ymthe.2017.09.010.

67. Day D, Hansen AR. Immune-related adverse events associated with immune checkpoint inhibitors. BioDrugs. 2016;30(6):571-84. https://doi. org/10.1016/j.ejca.2015.11.016.

68. Tanoue K, Shaw AR, Watanabe N, Porter C, Rana B, Gottschalk S, et al. Armed oncolytic adenovirus-expressing PD-L1 mini-body enhances antitumor effects of chimeric antigen receptor $T$ cells in solid tumors. Can Res. 2017;77(8):2040-51. https://doi.org/10.1158/0008-5472. CAN-16-1577.

69. Heo J, Reid T, Ruo L, Breitbach CJ, Rose S, Bloomston M, et al. Randomized dose-finding clinical trial of oncolytic immunotherapeutic vaccinia JX-594 in liver cancer. Nat Med. 2013;19(3):329-36. https://doi.org/10.1038/nm. 3089.

70. Pol J, Bloy N, Obrist F, Eggermont A, Galon J, Cremer I, et al. Trial watch Oncolmmunology. 2014;3(6): e28694. https://doi.org/10.4161/onci.28694.

71. VanSeggelen H, Tantalo DG, Afsahi A, Hammill JA, Bramson JL. Chimeric antigen receptor-engineered T cells as oncolytic virus carriers. Mol TherOncolytics. 2015;2:15014. https://doi.org/10.1038/mto.2015.14.

72. Rehman H, Silk AW, Kane MP, Kaufman HL. Into the clinic: talimogene laherparepvec (T-VEC), a first-in-class intratumoral oncolytic viral therapy. J Immunother Cancer. 2016;4(1):1-8. https://doi.org/10.1186/ s40425-016-0158-5.

73. Hatem Soliman, M.D., H. Lee Moffitt Cancer Center and Research Institute. (May 20, 2016 - October 28, 2021). Talimogene Laherparepvec in Combination with Neoadjuvant Chemotherapy in Triple Negative Breast Cancer. Identifier NCT02779855. Available from: https://clinicaltrials.gov/show/ NCT02779855.

74. Christopher Barker, MD Memorial Sloan Kettering Cancer Center. (June 30, 2016 - July 14, 2021). A Study of T-VEC (Talimogene Laherparepvec) With or Without Radiotherapy for Melanoma, Merkel Cell Carcinoma, or Other Solid Tumors. Identifier NCT02819843. Available from: https://clini caltrials.gov/show/NCT02819843.

75. Grimaldi AM, Marincola FM, Ascierto PA. Single versus combination immunotherapy drug treatment in melanoma. Expert Opin Biol Ther. 2016;16(4):433-41. https://doi.org/10.1517/14712598.2016.1128891.

76. Jiang X, Xu J, Liu M, Xing H, Wang Z, Huang L, et al. Adoptive CD8(+) $T$ cell therapy against cancer: challenges and opportunities. Cancer Lett. 2019;462:23-32. https://doi.org/10.1016/j.canlet.2019.07.017 Epub 2019/07/30. PubMed PMID: 31356845.

\section{Publisher's Note}

Springer Nature remains neutral with regard to jurisdictional claims in published maps and institutional affiliations.
Ready to submit your research? Choose BMC and benefit from:

- fast, convenient online submission

- thorough peer review by experienced researchers in your field

- rapid publication on acceptance

- support for research data, including large and complex data types

- gold Open Access which fosters wider collaboration and increased citations

- maximum visibility for your research: over $100 \mathrm{M}$ website views per year

At BMC, research is always in progress.

Learn more biomedcentral.com/submissions 